\title{
Plugging the Democracy Drain in the Struggle for Universal Access to Safe Drinking Water
}

Tara Paul

tapaul@indiana.edu

Follow this and additional works at: https://www.repository.law.indiana.edu/ijgls

Part of the Administrative Law Commons, International Law Commons, and the Water Law Commons

\section{Recommended Citation}

Paul, Tara (2013) "Plugging the Democracy Drain in the Struggle for Universal Access to Safe Drinking Water," Indiana Journal of Global Legal Studies: Vol. 20 : Iss. 1 , Article 16.

Available at: https://www.repository.law.indiana.edu/ijgls/vol20/iss1/16

This Note is brought to you for free and open access by the Law School Journals at Digital Repository @ Maurer Law. It has been accepted for inclusion in Indiana Journal of Global Legal Studies by an authorized editor of Digital Repository @ Maurer Law. For more information, please contactrvaughan@indiana.edu.

\section{$\Psi$}

JEROME HALL LAW LIBRARY

INDIANA UNIVERSITY

Maurer School of Law
Blooming ton 


\title{
Plugging the Democracy Drain in the Struggle for Universal Access to Safe Drinking Water
}

\author{
TARA E. PAUL*
}

\begin{abstract}
Privatization of water delivery services has become a global trend as states seek ways to shift both political and economic costs to private actors. The advantage of privatization is that it relieves governments of the daunting expense of repairing and expanding water infrastructure in order to improve quality and reach marginalized communities. But water privatization has also been deeply criticized for corrupt practices, increasing prices to the poor, undermining human rights objectives, and dodging accountability. This note aims to find middle ground, acknowledging that privatization is an important tool to increase freshwater access, but that treating water as a human right coupled with a strong legal framework that fosters transparency, public participation, and accountability will increase individual rights protections as well as the chances for successful privatization projects. South Africa's Promotion of Administrative Justice Act is offered as one example of how administrative law can be used to harmonize these objectives.
\end{abstract}

\section{INTRODUCTION}

Clean and affordable water is often taken for granted, but not in the minds of those who have experienced the want of it. Nearly one billion people lack access to clean, drinkable water.' Every year approximately

* J.D. Candidate, 2013, Indiana University Maurer School of Law; B.A. California State University, Fresno. I would like to thank Professors Christiana Ochoa and Robert Fischman for their guidance throughout the writing and editing process, and the Indiana Journal of Global Legal Studies staff for their help with preparation of this note. I am especially grateful to my family for their love and support through law school.

1. See Water Facts, WATER.ORG, http://water.org/water-crisis/water-facts/water/ (last visited Aug. 11, 2012) (listing 780 million people lack access to an "improved" water source).

Indiana Journal of Global Legal Studies Vol. 20, Issue 1 (2013)

(c) Indiana University Maurer School of Law 
3.4 million people die from water related illnesses. ${ }^{2}$ In addition to these profound implications for global health, lack of clean water and sanitation is intimately linked to poverty. Millions of women and children sacrifice precious time that could be spent in school or generating household income ${ }^{3}$ instead traveling long distances to collect water that is often of low quality and unhealthy for drinking. International organizations and non-governmental organizations (NGOs) have responded with development plans like the Millennium Development Project (MDP), a multi-national commitment to reduce poverty through the advancement of eight social and economic development goals. ${ }^{4}$ Such efforts have made access to water an international priority.

Addressing the access to water problem is a global concern, as both industrial and developing nations must develop strategies to effectively and affordably provide clean water to citizens, especially the poor. Two strategies in particular have emerged with a polarizing effect on the international discussion concerning the global water crisis. The first asserts that water should be treated as an economic commodity "to be priced, marketed, and managed by the private sector." ${ }^{\text {P }}$ Proponents of this strategy contend that the private sector has more expertise and economic capital than the public sector and will therefore be more efficient and capable of expanding to underserved communities. ${ }^{6}$ But supporters of the second strategy maintain that water is a human right under which all people must have access to clean fresh water in sustainable and affordable quantities. ${ }^{7}$ Pointing to privatization failures, these supporters reason that privatization creates opportunities for corporate conglomerates to exploit debt-ridden developing nations' resources and markets. ${ }^{8}$ Moreover, they argue that water is a public good that should not be bought and sold according to

2. See Billions Daily Affected by Water Crisis, WATER.oRG, http://water.org/watercrisis/one-billion-affected/ (last visited Aug. 11, 2012) (listing as the cause of death sanitation and hygiene-related causes).

3. $I d$.

4. See Millennium Development Goals, U.N. DEVELOPMENT PROGRAMME, http://www.undp.org/content/undp/en/home/mdgoverview/mdg_goals/mdg7/ (last visited Dec. 2, 2011) (listing as accomplishments of the seventh goal of the MDP to improve sustainability that access to water improvement has increased).

5. Barton H. Thompson, Jr., Water as a Public Commodity, 95 MARQ. L. REV. 17, 17 (2011).

6. Id. at 19 .

7. Id. at 18 .

8. Sarah I. Hale, Water Privatization in the Philippines: The Need to Implement the Human Right to Water, 15 PAC. RIM L \& POL'Y J. 765, 768, 777 (2006). 
the market. ${ }^{9}$ Each of these theories is infused with different implications for how water should be managed and who should manage it. But both sides of the debate ignore the realities of many less-developed nations and fail to recognize opportunities for collaboration. $^{10}$

Because water is an essential resource for human health and prosperity, the struggle to bring clean water to nearly one billion people and protect the health and development of marginalized groups are strong reasons to adopt a human right to water. But it must be recognized that privatization arguments also have merit. In developed and developing countries alike, the public sector has underperformed when it comes to providing water to all its citizens, and several common factors have prompted policy changes in favor of privatization. ${ }^{11}$ First, deteriorating water infrastructure is in need of repair and replacements call for enormous capital investments that are impossible for local governments to finance. ${ }^{12}$ Second, local governments are under political and economic pressure to choose privatization because the financial needs of the water sector are outstripping available domestic and foreign aid. ${ }^{13}$ Third, financially stressed governments are seeking private investment to increase access to clean water for underprovided communities. ${ }^{14}$ Finally, large water corporations have identified public water systems as opportunities for enormous profits and aggressively market their ability to make significant capital investments in infrastructure and operate water services. ${ }^{15}$ In addition, international financial institutions like the World Bank and the International

9. See generally DAVID A. MCDONALD \& GREG RUITERS, Theorizing Water Privatization in Southern Africa, in THE AGE OF COMMODITY: WATER PRIVATIZATION IN SOUTHERN AFRICA 13 (2005).

10. See generally Migai AKech, Privatization \& Democracy in East Africa: The PROMISE OF ADMINISTRATIVE LAW (2009) (arguing that increasing accountability in the privatization process will allow countries in East Africa to meet human rights obligations while also leveraging much needed private investment).

11. Craig Anthony Arnold, Water Privatization Trends in the United States: Human Rights, National Security, and Public Stewardship, 33 WM. \& MARY ENVTL. L. \& POL'Y REV. 785, 793 (2009).

12. Id. at 794 ("Estimates put the infrastructure investment needed in the US at $\$ 140-250$ billion in the next $20-30$ years").

13. Violeta Petrova, Note, At the Frontiers of the Rush for Blue Gold: Water Privatization and the Human Right to Water, 31 BRooK. J. INT'L L. 577, 586 (2006) (international financial institutions in particular).

14. Arnold, supra note 11, at 796-97 (ninety-three countries experienced privatization in 2000 , and many of the major multinational water service providers are operating in more than 100 countries).

15. Id. at 797 (estimating the combined revenue potential of three of the largest multinational water conglomerates-Veolia Environment, Suez Environment, and RWE $\mathrm{AG}-$ at approximately $\$ 3$ trillion). 
Monetary Fund (IMF) have pushed for increased private participation and decentralization in water since the $1980 \mathrm{~s} .{ }^{16}$ They have managed to promote this vision by conditioning development aid on privatization of water systems. ${ }^{17}$

Privatization has proven most successful when states remained actively engaged with good governance mechanisms and regulations. ${ }^{18}$ Though the state is necessary to privatization, "[it] is not a self-acting autonomous entity that inexorably acts with uniformity of purpose. Instead, the state is a contested frontier, and different actors-internal and external-all seek to influence how it works with a view to maximizing benefits and minimizing losses." 19 Capitulating to these pressures can lead to hasty decisions with minimal opportunities for public input and disastrous results for public health and government budgets. There are good reasons to contract with the private sector, but the treatment of water as a human right obligates states to ensure that all citizens have access to clean water. Regardless of public or private management, governments should protect human rights interests and maintain regulatory authority to avoid a slip into laissez-faire policies that accept market forces as a proxy for government regulation of such a crucial resource. $^{20}$

The purpose of this note is to demonstrate ways in which states can improve the governance of privatization to secure a human right to water through democratic accountability procedures. Procedures that include public law principles of transparency, public participation, and accountability foster citizen responsiveness to government decisions. ${ }^{21}$ Such procedures also offer avenues for citizens to participate in decisions to privatize and require actors to answer for policy decisions that are contrary to the public interest. This note argues that administrative law reforms offer the means for both public and private interests to be incorporated into legally binding procedures and thus, endeavors to find middle ground in the water privatization debate and offer a method for governments to protect human rights while also courting the private sector.

16. See Karen BaKker, Privatizing Water: Governance Failure and the WorLd'S URBAN WATER CRISIS 72 (2010) (discussing the World Bank).

17. Arnold, supra note 11, at 796.

18. AKECH, supra note 10 , at 17 .

19. Id.

20. Hale, supra note 8, at 783; see Alfred C. Aman, Jr., Privatization, Prisons, Democracy, and Human Rights: The Need to Extend the Province of Administrative Law, 12 IND. J. GLOBAL LEGAL STUD. 511, 518 (2005) (discussing a desire to avoid making hard political choices as a reason markets are allowed).

21. See Aman, supra note 20, at 516; AKECH, supra note 10, 31-33. 
Part I of this note will address the democracy drain, focusing on ways in which privatization can displace stakeholders and preclude citizen participation in policy making. Part II will elaborate on the commoditization versus human rights approaches to water, arguing that while there is room for private sector participation, a human right to water is preferable as a foundation for citizens to insist on good governance and accountability from state actors. This section will also examine a selection of global experiences of privatization to demonstrate the consequences when democratic accountability procedures are not available. Part III will explain how public law principles of transparency, public participation, and accountability can be employed to plug the democracy drain. This section will also examine South Africa's administrative law framework to demonstrate the potential for administrative law reforms to give meaning to human rights by applying public law principles to procedural requirements, applicable to both public and private entities.

\section{Describing the Democracy Drain Problem}

The democracy drain in privatization of government resources arises from the exclusion of stakeholders from economic policy decisions that will have immediate effects on their rights and livelihoods. ${ }^{22}$ The exclusion creates a gap between economic processes and citizen participation, leading to an erosion of government accountability and deregulation of markets. ${ }^{23}$ If governments take an increasingly hands-off approach, those that favor market outcomes may fill the void and regulate according to the rules of the market. ${ }^{24}$ When the role of the market and international decision makers become too augmented, "the public is no longer involved directly in decision-making, nor is information available in a form that would make public participation meaningful."25 Without meaningful participation and transparency, both public and private actors are able to avoid difficult political questions and choices. ${ }^{26}$

Commoditization of a public resource reinforces the loss of democracy, as market forces and market incentives become proxies for the public interest. Commoditization of water, if coupled with deregulation and minimal procedures for public input, may not only negatively impact citizens' access to water, but also broader policy

\footnotetext{
22. See Aman, supra note 20, at 517.

23. See id. at 518.

24. Id.

25. Id.at 517.

26. Id. at 518 .
} 
decisions. Commoditization is essentially a policy decision that limits the extent to which citizens will enjoy a certain benefit at the state's expense. ${ }^{27}$ The shift in financial costs is also a shift in political costs, allowing state actors to avoid tough political choices while private actors implement market operations with limited political impunity. ${ }^{28}$ As a result, commoditization can alter the agency relationship between citizens and the state. The value of democratic governance lies in its ability to foster legitimacy through public dialogue and processes. ${ }^{29}$ It calls for public participation in decision-making processes and seeks to hold actors accountable for actions and policies that are contrary to public will. ${ }^{30}$ Thus, democratic governance can be a strong accountability mechanism to balance market interests with individual interests. ${ }^{31}$ At the heart of democratic governance are public law elements of public participation, accountability, and transparency. ${ }^{32}$

\section{WATER AS A RIGHT, NOT A COMMODITY}

Underlying the privatization debate is the question of whether water can or should be treated as a commodity. Proponents of the commodity position argue that water should be managed with efficiency as the primary objective and that market forces will allocate resources to the most productive use. ${ }^{33}$ They maintain that privatization is the best means for reaching that goal because private entities are removed from political pressures and desires for reelection and therefore they are more likely to promote efficiency and minimize waste.$^{34}$ On the other end of the spectrum is the human rights approach. Proponents of this position argue that water must be managed with universal access to

27. $I d$.

28. Id.

29. Id. at $\mathbf{5 2 5 .}$

30. AKECH, supra note 10 , at 31 .

31. See generally Laura A. Dickinson, Government for Hire: Privatizing Foreign Affairs and the Problem of Accountability Under International Law, 47 WM. \& MARY L. REV. 135 (2005) (examining modes of accountability for private entities by examining the contractual relationship between the private entity and a government).

32. Aman, supra note 20 , at $\mathbf{5 2 5}$.

33. See Thompson, supra note 5, at 41 (examining how governments and markets can work together); AKECH, supra note 10, at 3-4 (referring to how free market economic theorists focus on efficiency as the goal in privatization).

34. See Jason Astle, Student Article, Between the Market and the Commons: Ensuring the Right to Water in Rural Communities, 33 DENV. J. INT'L L. \& POL'Y 585, 586-87 (2005); see also AKECH, supra note 10, at 3-4. 
clean drinking water as a primary objective, ${ }^{35}$ as privatization is perceived to inhibit access, especially to the poor. Moreover, they contend that water is a public good that must be managed by public actors who can be held politically accountable. ${ }^{36}$ Thus, while one approach is concerned with efficiency, the other is concerned with access and accountability. But these approaches are not necessarily incompatible. Because water is central to livelihood, there are significant risks to treating it as a commodity, but that does not preclude a role for privatization. Instead, access to water should be an enforceable right while states should consider private participation to help achieve access for all citizens.

\section{A. Consequences of Water as a Commodity}

Commoditization of a resource occurs through "practice or policy that promotes or treats a good or service as an article of commerce to be bought, sold, or traded through market transactions., ${ }^{37}$ Generally, for a good to be amenable to commoditization it must be excludable, such that access is granted based on ability to pay, and it must be rival, such that consumption by one individual effectively denies consumption by another. ${ }^{38}$ These characteristics make it possible to set competitive prices and allow the good to be influenced by the market. By contrast, something that is non-excludable and non-rival is resistant to commoditization and is considered a public good. ${ }^{39}$

Water does not fit particularly well into either category. ${ }^{40}$ It is difficult to describe it as excludable because its value is difficult to ascertain. Water is necessary for human survival, but it has many other uses also connected to human prosperity including religious practices, recreational enjoyment, agriculture, and environmental conservation

35. See, e.g., U.N. Dev. Programme, Human Development Report 2006: Beyond SCARCITY: POWER, POVERTY AND THE GLOBAL WATER CRISIS (2006), available at http:/hdr.undp.org/en/media/HDR06-complete.pdf.

36. See, e.g., ReClaiming PUblic Water: ACHIEvements, StRuggles AND Visions From AROUND THE WORLD (Belén Balanyá et al. eds., Belén Balanyá et al. trans., 2005), available at http://www.tni.org/sites/www.tni.org/archives/books/publicwater.pdf (providing an entire collection of articles on arguing for shifting away from privatization to allow for public accountability).

37. MCDONALD \& RUITERS, supra note 9, at 20.

38. Id. at 20 .

39. BAKKER, supra note 16 , at 30 (using the examples that any consumption of water means a rival use cannot occur and that consumption of water by one can reduce the benefits, or exclude, to others).

40. See MCDONALD \& RUITERS, supra note 9, at 22 (reviewing different properties of water and the markets around water). 
interests. ${ }^{41}$ Each of these important uses competes simultaneously for water consumption. On the other hand, water can be described as rival because it is a limited resource and one individual's consumption necessarily impacts the quantity available for others. ${ }^{42}$ Regardless of these difficulties, the foundation for the treatment of water as a commodity, particularly in urban areas, lies in its economic value created through the cost of providing it. ${ }^{43}$

The provision of clean water requires purification, construction and maintenance of an infrastructure for transportation, and delivery for individual consumption. ${ }^{44}$ Each step in the process adds a cost to the final product, and whether subsidized or charged the full price, a key component to commoditization is that the primary value is the cost of providing it. ${ }^{45}$ Once water is valued as a commodity, it loses its properties as a public good and is transformed into "a scarce monetized entity" subject to the same market forces as oil or gold. ${ }^{46}$ Cost recovery, efficiency in allocation and consumption, and profits become the primary objectives in water management. ${ }^{47}$

There are two common components of the commoditization of water that help reach these objectives. ${ }^{48}$ First, full-cost pricing to customers is used to recover the expense of providing water, but it is also an incentive for customers to be cautious in their consumption. ${ }^{49}$ Thus, individuals are reluctant to use more water than necessary, and water can be efficiently allocated among other competing interests. ${ }^{50}$ Second, commoditization encourages participation from the private sector, ultimately facilitating privatization through the transfer of state assets to private hands and the formation of contractual relationships for the construction, management, and operation of water infrastructure. ${ }^{51}$ Because private companies are believed to be accountable to customers

41. Id. at 21; BAKKER, supra note 16 , at 3 .

42. BAKKER, supra note 16 , at 30 .

43. See Bruce Pardy, The Dark Irony of International Water Rights, 28 PACE ENVTL. L. REV. 907, 914 (2011) (examining the various costs associated with getting water to urban areas).

44. Id.

45. See Thompson, supra note 5 , at $24-25$ (looking at commoditization as a way to increase conservation).

46. MCDONALD \& RUITERS, supra note 9 , at 19 .

47. Id. at 23.

48. See id. (reviewing the "corporatization" of water management).

49. See id. at $25-26$ (discussing benefits of full-cost pricing).

50. See id. at 55-56 (describing how allocation can often be between companies willing to pay and people who are not able to pay).

51. Id. at 23; See Thompson, supra note 5, at 28-29 (examining multiple countries that have undergone this privatization, including Chile, Mexico, Morocco, and the United Kingdom). 
rather than politics, proponents argue that the private sector is the more efficient manager of water. ${ }^{52}$

Despite the efficiency arguments, the commoditization of water has also been deeply criticized. Although privatization typically leads to increased access to water, it also almost always leads to significant increases in water prices that disproportionately affect the poor. ${ }^{53}$ Additionally, critics worry that governments too frequently decide to privatize "without proper regard to the prevailing political, social, and economic conditions." ${ }^{44}$

\section{Pitfalls: Global Lessons from Privatization Experiences}

Privatization of water delivery services in Cochabamba, Bolivia is a prototype of the pitfalls of experiences with private sector management of water utilities in developing countries. The Bolivian government received aid form the World Bank to revamp its urban water systems, and one of the conditions in the loan required Bolivia to reform those systems through privatization. ${ }^{55}$ Following the commodity approach to water, the World Bank believed that privatization could bring efficiency, lower prices, and the capital necessary to improve water services and infrastructures in developing countries when public entities had failed. ${ }^{56}$ In need of the aid, the Bolivian government complied with the condition and offered a concession to a private corporation. However, because of the high cost of the packaged development plan, it only attracted one bidder-Aguas del Tunari (AdT), which was controlled by a subsidiary of Bechtel Enterprises. ${ }^{57}$

From the outset, the contract was rife with exploitations and lack of transparency. The people of Cochabamba knew nothing of the plan to privatize the water systems, let alone who Bechtel or AdT were. ${ }^{58}$ The

52. Elizabeth a. Larson, at the Intersection of Neoliberal Development, SCARCE RESOURCES, AND HUMAN RIGHTS 10-11 (2010), available at http://digitalcommons.macalester.edu/intlstudies_honors/10/.

53. See Thompson, supra note 5 , at 38 (examining how privatization increases water prices).

54. AKECH, supra note 10 , at 6 .

55. Maria McFarland Sánchez-Moreno \& Tracy Higgins, No Recourse: Transnational Corporations and the Protection of Economic, Social, and Cultural Rights in Bolivia, 27 FORDHAM INT'L L. J. 1663, 1748 (2004).

56. See id. at 1748-49 (describing the failure of public entities to mean they were not a "credible provider" and the World Bank requiring the exploration of privatization).

57. Id. at 1750-51 (Aguas del Tunari's majority shareholder was International Waters Limited, which in turn was a subsidiary of Bechtel Enterprises, an American corporation).

58. Timothy O'Neill, Note, Water and Freedom: The Privatization of Water and its Implications for Democracy and Human Rights in the Developing World, 17 COLO. J. INT'L ENVTL. L. \& POL'Y 357, 365 (2006). 
negotiations with AdT were conducted in secret and the deal was only announced when the final contract was signed. ${ }^{59}$ As the only bidderand given Bolivia's need to privatize to receive the foreign aid-AdT was able to negotiate with the government for more favorable terms. ${ }^{60}$ For all the terms of the contract to be legal, Bolivia had to change the legal framework of its water laws such that the government could have complete property rights in water and then confer those rights to third parties. $^{61}$ The legislation was drafted hastily and pushed through despite strong opposition from indigenous groups and the public more generally. ${ }^{62}$ The new law significantly altered the principles of affordability and universal access that were essential to the original water laws. ${ }^{63}$

The fallout from the lack of transparency, public participation, and accountability was substantial. Prices soared by as much as 400 percent, partially due to the expense of tackling an infrastructure expansion under the contract, and communities that managed their water separately suddenly received water bills from AdT. ${ }^{64}$ Tens of thousands gathered in the capital to demand that the government terminate the contract, but they were answered with military and police aggression, from which many were injured and six were killed. ${ }^{65}$ The relationship between AdT and the government ended when AdT decided to leave the country, resulting in the return of water services to public control and the repeal of the water law statute. ${ }^{66}$

Lack of good governance has led to similar tales of demise for private water conglomerates on nearly every continent. Privatization in Manila, Philippines was the first large-scale water privatization venture in Asia in 1997, but it also had disastrous results. ${ }^{67}$ Prices increased between 500-700 percent, almost half of Manila's residents remained unconnected to water infrastructure, and in 2001, ninety-three percent

59. Sánchez-Moreno \& Tracy Higgins, supra note 55, at 1752.

60. O'Neill, supra note 58, at 366 (favorable terms to AdT included a 40-year lease on the city's water system, ability to tie rates to the U.S. Consumer Price Index, and install meters to monitor consumption from its meters as well as others).

61. Sánchez-Moreno \& Higgins, supra note 55, at 1759-61.

62. Id. at 1758-60 (Law 2029 on Potable Water Services and Sanitary Sewage was passed with virtually no opposition, no consultation with interested groups, and it was passed after only one forty-eight hour session such that the public had no time to react).

63. O'Neill, supra note 58 , at 367 .

64. Id. at 367-68.

65. Bechtel Co., Cochabamba and the Aguas del Tunari Consortium 4 (Dec. 2005), available at http:/www.bechtel.com/assets/files/PDF/Cochabamba_Fact\% 20Sheet_December_2005.pdf.

66. Sánchez-Moreno \& Higgins, supra note 55 , at 1771.

67. See Hale, supra note 8, at 772 (describing the effects of privatization as "diminish[ing] the public's access to quality water" and water being "less affordable"). 
lacked access to sanitation systems. ${ }^{68}$ Moreover, poor water treatment led to a cholera outbreak that infected hundreds and killed six, and E. coli contaminations were recorded at more than 700 percent of the regulatory standard. ${ }^{69}$ Virtually no meaningful improvements in the water delivery system eventually led to a complete restructuring of the contracts and management scheme. ${ }^{70}$

Atlanta, Georgia and Indianapolis, Indiana are two examples from the United States that brought in multinational private corporations to alleviate the financial burdens that water delivery put on the local governments. Shortly after entering into the contracts, prices and customer complaints soared, poor water treatment caused public boil notices, and there were allegations of corruption. ${ }^{71}$ Ultimately, both cities terminated the contracts and suffered millions of dollars in lost revenues due to unfulfilled contract obligations, renegotiations, and litigations. ${ }^{72}$

In Dar es Salaam, the government of Tanzania decided to privatize its water system and installed water meters to track usage and charge for full-cost recovery after decades of fully subsidizing water to citizens. $^{73}$ The government accepted a bid from a consortium led by Biwater, a British water corporation. But just two years after the contract was finalized, evidence of poor planning and underbidding on the part of Biwater caused the government to terminate the contract and incur millions in lost infrastructure repair expectations. ${ }^{74}$ Throughout the process, citizens were unaware of the privatization plan and were suddenly faced with soaring prices and water shut-offs. ${ }^{75}$ There was virtually no opportunity to express public concerns and documents were kept confidential such that not even Members of

68. Id.

69. Id. at 773 .

70. Id. at 768 .

71. See Arnold, supra note 11, 799-800 (discussing the outcome of privatization of water services in Atlanta); A Closer Look: Veolia Environment, FOoD \& WATER WATCH, Sept. 2010, available at http://www.foodandwaterwatch.org/factsheet/a-closer-look-veolia/ [hereinafter Fact Sheet] (discussing the outcome of privatization of water services in Indianapolis); Chris O'Malley, Consultant: Indianapolis Water Utility Lax in Overseeing Veolia, INDIANAPOLIS BUS. J., Oct. 17, 2009 (discussing some of the factors that led to the failure of privatization in Indianapolis).

72. See Arnold, supra note 11, at 800 (discussing the termination of a contract for private water services in Atlanta); Fact Sheet, supra note 71 (discussing the costs of terminating the contract for private water service in Indianapolis).

73. See AKECH, supra note 10 , at $63,66 \cdot 67$.

74. Id. at 67.69 .

75. Id. at 65-66; see also ROMILLY GREENHILL \& IRENE WEKIYA, ACTION AID INT'L, TURNING OFF THE TAPS: DONOR CONDITIONALITY AND WATER PRIVATIZATION IN DAR ES SALAAM (2004), available at http://www.actionaid.org.uk/doc_lib/turningoffthetaps.pdf. 
Parliament were permitted to review them. ${ }^{76}$ The executive was effectively able to push the privatization plan through with virtually no check on its power. ${ }^{77}$

Despite these pitfalls, many countries, including the United States, the Philippines, and Tanzania, still contract with the private sector because the local governments are mired in budget constraints and simply do not have the capital to make water utilities operationally viable. $^{78}$

\section{Promises: Arguments Supporting Private Sector Participation}

Despite abundant accounts of privatization failures from opponents, there are still important reasons for governments to consider private sector participation. In developing nations, private sector investment is likely to be a fundamental component to expanding access. Moreover, developed countries must confront extraordinary financing demands to repair and maintain aging water infrastructure. ${ }^{79}$ For instance, the American Society of Civil Engineers (ASCE) released its report on the status of the United States' overall infrastructure in $2009 .^{80}$ The results were dismal. ${ }^{81}$ The ASCE gave drinking water and wastewater systems a D: rating, observing that aging pipes "lose an estimated 7 billion gallons of drinking water per day" and that it would take more than " $\$ 11$ billion in additional funding each year just to bring drinking water systems into compliance with federal regulations." ${ }^{\text {"2 }}$ President Barack Obama addressed the dire state of water infrastructure in the economic stimulus package signed into effect in 2009 , but the bill only allocated $\$ 2$ billion for drinking water and $\$ 4$ billion for wastewater projects. ${ }^{83}$ The stimulus package offers hope for addressing the challenge of maintaining the nation's access to water, but it also demonstrates that

76. AKECH, supra note 10 , at 66 .

77. Id.

78. See generally Craig Anthony Arnold, Privatization of Public Water Services: The States' Role in Ensuring Public Accountability, 32 PEPP. L. REV. 561, 569 (discussing the United States); Hale, supra note 8 (discussing the Philippines); AKECH, supra note 10, at 62 (discussing Tanzania).

79. Arnold, supra note 78 , at 570 .

80. Ed Hightower, With US Infrastructure in Tatters, Stimulus Plan Offers Paltry Sum, WORLD SOCIALIST WEB SITE (Feb. 14, 2009), www.wsws.org/articles/2009/ feb2009/infr-f14.shtml.

81. Id. (the report gave the overall status of the nation's infrastructure a " $\mathrm{D}$ " grade).

82. Id.

83. Press Release, American Water Works Ass'n, Stimulus Legislation Small Step Forward in Addressing Water Needs (Feb. 17, 2009), available at http://www.drinktap.org/mediadnn/Portals/6/PressReleases/02_17_09_stimulus_signing.pd f. 
the challenge is daunting and more capital must be obtained by other means. Thus, private participation offers enticing answers.

Proponents of privatization point to the financial limitations of the public sector, coupled with examples of the public failures to efficiently manage water resources, as the primary justifications for the trend toward privatization of water resource management. ${ }^{84}$ Advocates specifically point to examples of corruption, inefficiency, susceptibility to political influences, poorly maintained infrastructure, and lack of investment under public management of water resources. ${ }^{85}$ There are examples in which these flaws, as well as subsidies, directly contributed to lower prices and greater access to clean water and sanitation for upper- and middle-income groups while poor communities paid more and suffered from stifled access to water. ${ }^{86}$

We can look to the situation before and after the contract with AdT in Bolivia as examples of public sector shortcomings. Prior to the government's contract with AdT, the municipal water agency-Servicio Municipal de Agua Potable y Acantrillado (SEMAPA) - controlled the water utilities. ${ }^{87}$ Residents in Cochabamba faced constant water shortages; half of the city was not even connected to the water system; SEMAPA's tariff scheme was such that the heaviest users were charged less than low-water users; approximately 50 percent of transported water was lost; quality was not monitored; the system was operating at a loss of $\$ 2.25$ million per year; and the gross inefficiencies led to rationing. ${ }^{88} \mathrm{~A}$ combination of political corruption and foreign debt are blamed as the factors that crippled SEMAPA. ${ }^{89}$

Almost ten years after the dissolution of the contract with AdT, Cochabamba's water system is back in the hands of SEMAPA and residents are once again experiencing water shortages—or no service at all-and higher rates. ${ }^{90}$ In 2009, Bolivia enacted a new Constitution

84. See World Bank Group, Sustaining Water for All in a Changing Climate: WORLD BaNK GROUP IMPLEMENTATION PROGRESS REPORT OF THE WATER RESOURCES SECTOR STRATEGY 40-44 (2010) [hereinafter WORLD BANK 2010 REPORT], available at http://water.worldbank.org/water/publications/sustaining-water-all-changing-climateworld-bank-group-implementation-progress-report (discussing World Bank strategies for developing public-private partnerships in the water sector).

85. Petrova, supra note 13 , at 587.

86. Id.

87. Sánchez-Moreno \& Higgins, supra note 55, at 1748.

88. O'Neill, supra note 58, at 363-65.

89. Id. at 364 .

90. Morgan McDonald, Note, Assessing the New Wave: Transaction Costs of Water Law Reform in Latin America, 17 SW. J. INT'L LAW 175, 191 (2011). 
that guarantees access to clean drinking water as a fundamental human right, but expressly forbids private investment in water services: ${ }^{91}$

Every person has the right to universal and equitable access to basic services of potable water. . . . It is the responsibility of the State, at all levels of government, to provide basic services through public, mixed, cooperative or community entities. . . Access to water and sewer systems are human rights, are not the object of concession or privatization, and are subject to a regimen of licensing and registration, in accordance with the law. ${ }^{92}$

Bolivia continues to be in desperate need of infrastructure repair, but the government has failed to make the necessary investments. ${ }^{93}$ Consequently, SEMAPA cannot meet the needs of its customers, and the government's failure to provide access has essentially placed it in direct violation of its own human rights provision.

Privatization can address these shortcomings by offering desperately needed financing to improve infrastructure and increase water delivery, thereby improving the possibility for widespread access to clean, drinkable water. Additionally, it relieves the political risks public actors might face if public management failed and places this risk on private entities less susceptible to political influences. ${ }^{94}$ Privatization remains an important mechanism for states to achieve access to water for all citizens while also promoting efficiency and conservation through more accurate pricing. ${ }^{95}$

Yet examples of privatization in Bolivia, the Philippines, Tanzania, and the United States also demonstrate that some of the shortcomings of public management can also be seen in private management. Prices for water remain high in Bolivia under public management, and private

91. Id.

92. Nueva Constitución Política del Estado [C.P.] art. 20(I)-(III) (2009) (Bol.), translated in WORLD CONSTITUTIONS ILLUSTRATED (Jefri Jay Ruchti ed., Embassy of Bol. trans., 2011).

93. See McDonald, supra note 90, at 191-92; Sánchez-Moreno \& Higgins, supra note 55, at 1774 .

94. See Elliot Curry, Comment, Water Scarcity and the Recognition of the Human Right to Safe Freshwater, 9 Nw. U. J. INT'L HUM. RTS. 103, 113 (2010) (discussing the shifting of risk being desirable when governments already fail to provide adequate water).

95. See MCDONALD \& RUITERS, supra note 9 , at 18 (discussing the benefits of corporatization and privatization of water, such as creating a transparent form of accounting allowing "hidden" costs to be seen). 
management in Indianapolis did not yield the expected financing for infrastructure. ${ }^{96}$

If privatization of water is to be implemented effectively such that it does not compromise the livelihood of citizens and achieves desired efficiency results, "there is a need to establish institutional mechanisms that will enable citizens to participate in their formulation, and hold governments and private actors accountable for the implementation and consequences of such process." ${ }^{97}$ One available mechanism is the presence of enforceable rights in domestic laws. Rights provide the foundation upon which citizens may make demands against their governments. But more significantly, it is a substantive platform upon which citizens may stand and require powerful public and private actors to account for their decisions.

\section{B. Water as a Human Right}

\section{Current Status of Water in International Law}

Several forms of international documentation either explicitly or implicitly support a right to water. International human rights treaties create binding obligations on state parties to fulfill the commitments enshrined in the text. ${ }^{98}$ As such, treaties are the strongest source for an investigation of international law regarding a right to access to clean drinking water. Next are forms of non-binding norms developed through the United Nations, often through declarations, principles, or guidelines. $^{99}$ These sources are useful for defining the right to water, and, although they do not carry the force of law, they at least demonstrate political commitments among states to implicitly provide a right to access to clean drinking water.

A handful of international treaties explicitly reference state responsibilities concerning water, but they fall short of ensuring a general or individual claim against the state for accessibility to clean drinking water. The treaties with the clearest provisions concerning water are the Convention for the Elimination of Discrimination Against

96. For other examples of water privatization shortcomings, see Petrova, supra note 13, at 589-90 (discussing privatization of Manila's water system in the Philippines); see also McDonald, supra note 90 , at 185.202 (discussing privatization of water systems in Bolivia, Argentina, and Uruguay).

97. AKECH, supra note 10 , at 31 .

98. Knut Bourquain, Freshwater access from a Human Rights Perspective: A CHALLENGE TO INTERNATIONAL WATER AND HUMAN RIGHTS LAW 12-13 (2008).

99. See International Law, OFFICE OF THE UNITED NATIONS HIGH COMMISSIONER FOR HUMAN RIGHTS, http:/www2.ohchr.org/english/law/ (last visited Nov. 10, 2012) (providing access to the text of a multitude of conventions and protocols). 
Women (CEDAW), the Convention on the Rights of the Child (CRC), and the Convention on the Rights of Persons with Disabilities (CRPD). The CEDAW was developed to bring women's rights into the forefront of human rights discussions and focused on the legal and cultural restrictions on the equality of women. ${ }^{100}$ Water is mentioned within the context of the specific obstacles women in rural settings face under Article 14, which requires states parties to take necessary steps to ensure that such women are able " $[\mathrm{t}] \mathrm{o}$ enjoy adequate living conditions, particularly in relation to housing, sanitation, electricity and water supply, transport and communications." 101

The CRC was similarly constructed to bring the interests of children to the forefront of human rights considerations. ${ }^{102}$ It discusses water within the context of every child's right to "the highest attainable standard of health." ${ }^{03}$ In particular, states must take steps to provide "adequate nutritious food and drinking water" to combat disease and malnutrition among children. ${ }^{104}$ Article 28 of the CRPD is another source of international law in which water is mentioned. ${ }^{105}$ It provides for an adequate standard of living and requires states parties to "ensure equal access by persons with disabilities to clean water services, and ensure access to appropriate and affordable services, devices and other assistance for disability-related needs." 106

International humanitarian law also expressly protects access to water during violent conflicts. ${ }^{107}$ The Third Geneva Convention on the Treatment of Prisoners of War requires prisoners of war to receive a sufficient supply of drinking water and the Fourth Geneva Convention on the protection of civilians during times of war and Additional Protocols I and II guarantee the same right to civilian internees. ${ }^{108}$ However, these rights are guaranteed within the context of violent

100. See generally Convention for the Elimination of All Forms of Discrimination Against Women, adopted Dec. 18, 1979, 1249 U.N.T.S. 13 [hereinafter CEDAW].

101. Id. at art. 14, ๆ 2(h).

102. See generally Convention on the Rights of the Child, adopted Nov. 20, 1989, 1577

U.N.T.S. 3 [hereinafter CRC].

103. Id. at art. 24 , I 1.

104. Id. ๆ 2.

105. Id. at art. 28.

106. Convention on the Rights of Persons with Disabilities art. 28, I 2(a), adopted Dec. 13, 2006, 2515 U.N.T.S. 3 [hereinafter CRPD].

107. See, e.g., Geneva Convention Relative to the Treatment of Prisoners of War, adopted Aug. 12, 1949, 75 U.N.T.S. 135.

108. BOURQUAIN, supra note 98, at 124 (citing Articles 20,26, 29, and 46 of the Geneva Convention III in regards to prisoners of war; Articles 85, 89, and 127 of the Geneva Convention IV and Articles 5(1)(b) and 14 of the Additional Protocol II for civilian internees). 
conflict only, and therefore, neither amount to a general, individual right to water. ${ }^{109}$

Despite explicit mentions of water in each of these international treaties, none of them actually provide a general right to clean freshwater that an individual can assert against the state. In the CRC, providing clean water is only one of a handful of positive actions the state can take to meet its obligation to protect the health of children. ${ }^{110}$ The CEDAW is also limited because it applies protections for a right to access to water even more narrowly within the context of discrimination against rural women. ${ }^{111}$ The $\mathrm{CRC}$, though more comprehensive, contemplates water rights merely as a function of health, ${ }^{112}$ and the Geneva Conventions are similarly limited because they only apply during times of conflict. ${ }^{113}$

The two primary international treaties on human rights that implicitly support a human right to water are the International Covenant on Civil and Political Rights (ICCPR) and the International Covenant on Economic, Social, and Cultural Rights (ICESCR). These human rights treaties require states to "take appropriate steps" to protect rights to life, to an adequate standard of living, to food, and to health-rights in which access to water is implicitly necessary for their realization. ${ }^{114}$ The existence of an implied human right to clean drinking water through the combination of these treaties appears strong, but the ICCPR and the ICESCR are also weak foundations for a right to water. For instance, the ICCPR states, "no one shall be arbitrarily deprived of his life." 115 The term "arbitrary" implies that there are some instances in which a non-arbitrary deprivation could be justified. ${ }^{116}$ Thus, as long as individuals are able to find water, the state has no direct obligation under the ICCPR to take steps to increase water access. The ICESCR "recognize[s] the right of everyone to an adequate standard of living."117 But to realize an adequate standard of living for citizens, much more water must be provided and for many more uses than needed for

109. Id

110. CRC art. 24, ๆ 1.

111. BOURQUAIN, supra note 98 , at 198 .

112. Id.

113. Id. at 124 .

114. International Covenant on Civil and Political Rights art. 6, \ 1, adopted Dec. 19, 1966, 999 U.N.T.S. 171 [hereinafter ICCPR] (explaining that "[e]very human being has the inherent right to life"); International Covenant on Economic, Social and Cultural Rights arts. 11-12, adopted Dec. 16, 1966, 993 U.N.T.S. 3 [hereinafter ICESCR] (explaining that every human has the right adequate food, housing, and good health).

115. ICCPR art. 6, I 1 (emphasis added).

116. BOURQUAIN, supra note 98 , at $125-26$.

117. ICESCR art. 11, ๆ 1. 
survival. ${ }^{118}$ This includes water for farming, hygiene and sanitation, drinking and cooking, all in adequate amounts. ${ }^{119}$ Moreover, the mandate for states to "take steps" to protect the human rights curbs the imposition of a direct state obligation, ${ }^{120}$ especially an obligation to provide a resource that is not expressly mentioned. Thus, these treaties fall short of guaranteeing an individual claim because any requirement for the state to provide clean drinking water is only inferred.

\section{Progress toward Actualization of a Human Right to Water in International Law}

To directly address this lacuna in international human rights law, the U.N. General Assembly, in 2010, passed Resolution 64, expressing its recognition of the "right to safe drinking water and sanitation as a human right that is essential for the fulfillment of life and all human rights." ${ }^{121}$ Resolution 64 was met with broad international support with a large majority of members voting in its favor. ${ }^{122}$ Later that year, the U.N. Human Rights Council reaffirmed the General Assembly's findings and issued a similar resolution stating that "the human right to safe drinking water and sanitation is derived from the right to an adequate standard of living and inextricably related to the right to the highest attainable standard of physical and mental health, as well as the right to life and human dignity." "123 The Council also expanded on states' responsibilities as the principle guardians of human rights. ${ }^{124}$ It called upon states to develop strategies, legislation, and regulation; to guarantee transparency and community participation in the planning and implementation process; to ensure non-discrimination so that the right will be realized for all; to safeguard the availability of effective remedies; and to require that accountability mechanisms are in place. ${ }^{125}$ Finally, the Council emphasized that even when water delivery services

118. BOURQUAIN, supra note 98 , at 139.

119. Id.

120. Id. at 141 .

121. G.A. Res. 64/292, at 2, U.N. Doc. A/RES/64/292 (July 28, 2010).

122. Press Release, General Assembly Adopts Resolution Recognizing Access to Clean Water, Sanitation as Human Right, By Recorded Vote of 122 in Favour, None Against, 41 Abstentions, U.N. Press Release GA/10967 (July 28, 2010) (stating no countries opposed, but that the United States was one of forty-one countries that abstained).

123. Human Rights Council Res. 15/9, Res. on Human Rights and Access to Safe Drinking Water and Sanitation, 15th Sess., Sept. 30, 2010, U.N. Doc. A/HRC/Res/15/9, at 2 (Sept. 30, 2010).

124. See id. at 3 (listing the states' responsibilities with regard to human rights).

125. $I d$. 
are delegated to non-state actors, the state continues to bear the responsibility to ensure the realization of the human right. ${ }^{126}$

Neither of these resolutions created binding international law, ${ }^{127}$ but they imply a commitment to establish a binding right to water in the future. However, an increasing number of countries have recognized a human right to water in their domestic laws. ${ }^{128}$

\section{State Recognitions of a Human Right to Water}

Since the state of international law on access to water is nebulous, the existence of a human right to water is strongest under national law. Several states recognize a human right to water, either explicitly through provisions in their Constitutions or implicitly through court interpretations of pre-existing rights. ${ }^{129}$ Constitutions are the strongest source of rights protections, and several nations provide explicit rights to drinking water. ${ }^{130}$ Moreover, national courts have upheld corporate obligations to respect the right to water, demonstrating a willingness to enforce those human rights guarantees. ${ }^{131}$

Presently, the Constitutions of several countries explicitly provide for a right to clean water. ${ }^{132}$ In Africa, these include the Democratic Republic of the Congo, Ethiopia, Gambia, Kenya, South Africa, Uganda, and Zambia; ${ }^{133}$ in the Americas, Bolivia, Ecuador, Nicaragua, Uruguay,

126. $I d$.

127. See International Law, supra note 99 (explaining that resolutions do not create binding law).

128. See, e.g., The Rights to Water and Sanitation in National Law, THE RIGHT To WATER AND SANITATION, http://www.righttowater.info/progress-so-far/national-legislationon-the-right-to-water/ (last visited April 25, 2012) (listing countries that provide a right to clean water).

129. Jernej Letnar Černič, Corporate Obligations Under the Human Right to Water, 39 DENV. J. INT'L L. \& POL’Y 303, 320 (2011).

130. Id.

131. For example, the Constitution of India guarantees a right to life but has no explicit right to water. INDIA CONST., art. 21. Nevertheless, the Supreme Court of India interpreted the right to life to include rights "to food, water, decent environment, education, medical care and shelter." Chameli Singh v. State of Uttar Pradesh A.I.R. 1996 S.C. 1051, I 8 (India). It later re-affirmed its commitment to a human right to water, stating "water is fundamental to life and there is a duty on the state under Article 21 to provide clean drinking water to its citizens." A.P. Pollution Control Board v. Prof. N.V. Nayudu, (2001) 4 I.L.R. 657, If 3 (India).

132. The Rights to Water and Sanitation in National Law, supra note 128.

133. Id.; CONST. OF THE DEM. REP. CONGO May 13, 2005, art. 48 (providing for the right to decent housing as well as potable water); CONST. OF FED. DEM. REP. OF ETH. Dec. 8, 1994, art. 90 (providing a right to water to the extent that the state can provide it); CoNST. OF REP. OF GAM. 1997, art. 216(4) (providing the state must endeavor to provide equal access to clean, safe water); ConSTITUTION, art. 43(1)(d) (1992) (Kenya) (providing 
and the United States-specifically, Massachusetts and Pennsylvania. ${ }^{134}$ An additional handful of states have recognized a human right to water as inferred from other existing constitutional rights. These countries include India, Colombia, and Belgium, among others. ${ }^{135}$ Meanwhile, other countries are currently considering a right to water in their Constitutions, including Mexico and Colombia. ${ }^{136}$

\section{Privatization and Human Rights in South Africa: A Progressive Constitution and a "Reasonable" Court}

South Africa's recognition of a human right to water is particularly significant for three reasons. First, the country enjoys global recognition for its progressive Constitution and Constitutional Court, which provides and protects socioeconomic rights, including the right to water. ${ }^{137}$ Second, South Africa was the first nation in the world to hear a case concerning the right to water in its highest court, setting an important precedent for future litigation on the right to water that can

everyone has a right to water in "adequate quantities and reasonable quality"); S. AFR. CONST, art. 27, 1996 (providing a right to "sufficient" water); CONST. OF REP. OF UGANDA Oct. 8, 1995, Objective XIV ("The state shall endeavor to ensure that . . all Ugandans enjoy . . . clean and safe water"); CONST. OF ZAMBIA of 1991 (as amended by Act No. 18 of 1996), art. 112 ("The state shall endeavor to provide clean and safe water").

134. The Rights to Water and Sanitation in National Law, supra note 128; CONSTITUCIÓN POLfTICA DE BoLIVIA [C.P.] art. 20(I), (III) (2009) (everyone has a universal and equitable right of access to potable water, which is a human right, and privatization of water services is prohibited); POLITICAL CONSTITUTION OF REP. OF EQUADOR Oct. 20, 2008, art. 276(4) (providing for "permanent and quality access to water"); CONSTITUCIÓN Política de la RePúbliCA DE NiCARAGUa [CN.] tit. VI, ch. I, art. 105, LA GaCETA, Diario OFICLAL [L.G.] 16 September 2010 (the state is obligated to provide public services including water and the public has an inalienable right of access to these services); CONSTITUCión Polf́tica DE LA ReP. ORIENTAL DEL URUguaY [C.P.] 1967, art. 47 (confirming that access to drinking water is a fundamental human right); MASS. CONST. art. 49 ("The people shall have a right to clean air and water."); PA. CONST. art. 1, §27 (guaranteeing a right to "pure water" and the state government must protect water among other resources for the benefit of the people).

135. See The Rights to Water and Sanitation in National Law, supra note 128 (listing numerous countries that have recognized a right to water).

136. See Another Victory for the Human Right to Water in Mexico, UNITARIAN UNIVERSALIST SERV. COMM. (Feb. 8, 2012), http://www.uusc.org/article/2012/01/01/ another_victory_for_the_human_right_to_water_in_mexico (explaining that Mexico will soon recognize the human right to water and sanitation in their Constitutions); Andrew Willis Garcés, Colombia: Fighting Development Banks for the Human Right to Water, UPSIDE DOWN WORLD (Mar. 30, 2009, 10:49 AM), http://upsidedownworld.org/main/ content/view/1786/1/ (explaining that coalitions and consumer organizations have been organizing since 2007 to add a human right to water to the Constitution).

137. LARSON, supra note 52 , at 6 . 
serve as a model for enforcement in other developing countries. ${ }^{138}$ Finally, South Africa's water policies create a unique setting that reflects the convergence of progressive socioeconomic rights enshrined in a Constitution and entrenched neoliberal economic policies, influenced by its long-term relationship with the World Bank. ${ }^{139}$ These factors make South Africa a vibrant example for exploring the enforcement of a human right to water, and also demonstrate that there are possibilities for privatization to operate within a human rights framework.

South Africa's post-apartheid Constitution is a body of national law that endeavors to reflect socioeconomic rights available in international laws such as the ICESCR as well as the African Charter of Humans and People's Rights. Section 27 of the Constitution addresses the human right to water:

(1) Everyone shall have the right to have access to-(a) health care services, including reproductive health care; (b) sufficient food and water; and (c) social security .... (2) The state must take reasonable legislative and other measures, within its available resources, to achieve the progressive realization of each of these rights. ${ }^{140}$

Since the adoption of this Constitution, South Africa has also actively engaged the private sector in the management and expansion of its water delivery systems with the assistance and guidance of the World Bank. ${ }^{141}$

Mazibuko v. City of Johannesburg (Mazibuko) is the seminal case in which the Constitutional Court directly addressed the right to water and clarified the state's constitutional obligations within the context of privatization. ${ }^{142}$ In 2001, Johannesburg privatized its municipal water delivery system, creating Johannesburg Water, to "leverage private sector expertise to build a financially viable and efficient water and sanitation entity." "143 Johannesburg Water then entered a five-year contract with Johannesburg Water Management (JOWAM), a joint

138. Id.

139. Id.

140. S. AFR. CONST., art. 27, 1996 (emphasis added).

141. Suez alone was involved in at least seven different water privatization contracts between 1986 and 2001. See Suez in South Africa, PUBLIC CITIZEN, available at http://www.citizen.org/documents/suezinsouthafrica.pdf (last visited Aug. 23, 2012).

142. See generally Mazibuko v. City of Johannesburg 2010 (4) SA 1 (CC) (S. Afr.).

143. Water Dialogues-South AFrica, Discussion Document on Cross CutTing ISSUES (2009), available at www.waterdialogues.org/south-africa/downloads/Att-17.doc. 
venture between the multinational corporation Suez and its subsidiaries in the United Kingdom and South Africa. ${ }^{144}$ According to the contract, JOWAM was responsible for the day-to-day operations of Johannesburg Water. ${ }^{145}$

The plaintiffs in Mazibuko were residents of Phiri Township, an apartheid-era settlement for Sotho and Tswana peoples in Soweto, on the outskirts of Johannesburg. ${ }^{146}$ The exceptionally densely populated neighborhood dealt with inadequate water supply due to decades-old, leaking water pipelines. ${ }^{147}$ Soweto residents had been paying a flat rate for water use based on an assumed use of twenty kiloliters per household, but Johannesburg Water observed that actual consumption in Soweto was more than triple that figure. ${ }^{148}$ Johannesburg Water estimated that up to 75 percent of Soweto water was not paid for, although it is uncertain whether this was because of non-payment or water lost through dilapidated piping. ${ }^{149}$ Cost recovery was integral to the privatization plan, so JOWAM initiated project Gcin'amanzi, in which pre-paid meters were installed in Phiri to improve customer payments and achieve "sustainable results."

While residents were guaranteed a free minimum amount of water through the government's Free Basic Water Policy (six kiloliters per household per month), many could not afford additional water to meet their daily needs. ${ }^{151}$ Although two other payment schemes were available, the plaintiffs claimed they were only informed of, and had to accept, the pre-paid meter installations, which if the pre-paid meter was not installed the water was shut off. ${ }^{152}$ All plaintiffs with pre-paid meters indicated that subsidized water provisions did not last beyond the middle of each month, causing families to constantly ration their water. ${ }^{153}$ Families caring for sick family members especially struggled to find the means to pay for more water and ration what they had. ${ }^{154}$ The plaintiffs alleged that the pre-paid meter project represented a

144. Carina Van Rooyen, et al., Water Dialogues, Johannesburg Case Study 17 (2009), available at http://www.waterdialogues.org/south-africa/documents/ JohannesburgCaseStudy-FullReport.pdf (last visited April 25, 2012).

145. Id. (Suez owned $66 \%$ of the shares).

146. LARSON, supra note 52 , at 40.

147. Id. (180 persons per hectare).

148. Mazibuko, 2010 (4) SA 1 (CC) at 6 para. 11.

149. Id. at 7 para. 12 .

150. SUEZ ENVIRONMENT, WATER STORIES: JohANNESBuRg WATER CONTRACT 9 (2010), available at $\mathrm{http} / / \mathrm{www}$.suez-environnement.ff/wp-content/uploads/2010/07/water_stories_ johannesburg_fr_bd_21-06-10.pdf.

151. See LARSON, supra note 52, at 41-42.

152. Mazibuko, 2010 (4) SA 1 (CC) at 8 para.16.

153. LARSON, supra note 52, at 41-44.

154. Id. 
regression from the constitutional requirement for "progressive realization" of the right to water; that the free six kiloliters per household per month was unconstitutional because it did not provide a sufficient amount of water as required under the Constitution; and that the limitation to six kiloliters indirectly discriminated against poor black Africans who live in larger households and cannot afford more water beyond the subsidized amount. ${ }^{155}$

The Constitutional Court disagreed, concluding that both the six kiloliters per household under the Free Basic Water Policy and the prepaid meters were constitutional. ${ }^{156}$ It based its decision on a prior case, Government of the Republic of South Africa v. Grootboom, which dealt with the right to housing under Section 27 of South Africa's Constitution. In Grootboom, the Constitutional Court held that Section $27(1)$ does not create "absolute or unqualified" rights without more. ${ }^{157}$ Rather, subdivision (1) must be read in conjunction with the state's obligations in subdivision (2) to fulfill those rights within reasonable means. ${ }^{158}$ Applying Grootboom to water, the court held that the state is not obligated to provide every person with sufficient water, but must take reasonable steps "to reali[ze] the achievement of the right of access to sufficient water, within available resources." 159 In other words, as long as the state is taking some action to achieve sufficient access to water, it is meeting its constitutional obligations.

Applying the reasonableness test adopted in Grootboom, the Court found that the current pricing schemes for water and pre-paid meters were all constitutionally reasonable steps toward the realization of the right to water. ${ }^{160}$ Influential to the Court's conclusion was the state burden of adopting alternatives: the complexities of Johannesburg's water infrastructure; the difficulty of determining the number of people living in each Johannesburg home so that water could be subsidized per person rather than per household; and the fact that the heavier water users were charged more to fund the subsidies for poor neighborhoods. The court found all of these factors indicative of a reasonable water policy. ${ }^{161}$ Moreover, the Court held that it would be improper to determine what is "sufficient," stating it was a matter for "the institutions of government best placed to investigate social conditions in

155. Id. at 44 .

156. Mazibuko, 2010 (4) SA 1 (CC) at 5-6 para. 9.

157. Government of the Republic of South Africa v. Grootboom 2001 (1) SA 46 (CC) at para. 38 (S. Afr.).

158. Mazibuko, 2010 (4) SA 1 (CC) at 25 para. $49-50$.

159. Id. (emphasis added).

160. See id. at 82 para. $156-57$ (discussing what it requires to be reasonable).

161. Id. at $42-49$ para. $84-97$. 
light of available budgets and to determine what targets are achievable in relation to social and economic rights." 162

The Mazibuko case has received both resounding praise as well as deep criticism from the international community. ${ }^{163}$ For some, the Court trounced human rights interests with neoliberal economic development arguments. ${ }^{164}$ But such criticism is less compelling when states must balance rights with limited resources. A reasonableness test can be a useful approach for giving a state flexibility in the endeavor to meet constitutional obligations within budget and resource allocation constraints. Furthermore, establishing a bare minimum quantity and quality allocation of water to all individuals is a technical decision best left to policymakers and the more democratic branches. Although the outcome of Mazibuko may not have been ideal for the citizens of Phiri, the virtue of the Court's decision is that it necessitates democratic accountability in the legislative and executive branches. Government actors must make reasonable policy choices in the administration of water delivery and continue to make progress toward the realization of the right to water.

In this way, the Constitutional Court effectively filled a void in international discourse concerning the human right to water: it went beyond the recognition of a human right and articulated a feasible path for the state to meet human rights obligations, urging reasonable and democratically accountable policy decisions from legislators and executives. ${ }^{165}$ The reasonableness test may not be perfect, but it lays the foundation for better governance and stronger democratic accountability procedures.

162. Id. at 30 para. 61 .

163. Compare Paul O'Connell, The Death of Socio-Economic Rights, 74 MODERN L. REV. 532, 551-52 (2011) (criticizing the case for undermining socio-economic rights and returning to the neo-liberal approach to development) with Rep. of the Special Rapporteur on the Human Right to Safe Drinking Water and Sanitation, Compilation of Good Practices, If 96, Human Rights Council, U.N. Doc. A/HRC/18/33/Add.1 (June 29, 2011) (by Catarina de Albuquerque) (pointing to Mazibuko as an example of litigation that helps realize the right to water).

164. See generally LARSON, supra note 52 (examining the Mazibuko case in South Africa and how economic globalization in developing nations with constrained budgets can compete with issues raised by human rights).

165. See Mazibuko, 2010 (4) SA 1 (CC) at 30 para. 61; see also Eric C. Christiansen, Adjudicating Non-Justiciable Rights: Socio-Economic Rights and the South African Constitutional Court, 38 Colum. HuM. RTS. L. REv. 321, 323-24 (2007); What Price for the Priceless? Implementing Justiciability of the Right to Water, Note, 120 HARV. L. REV. 1067, 1087-88 (2007); but see O'Connell, supra note 163. 


\section{Plugging the Democracy Drain AND the APPLiCability of ADMINISTRATIVE LAW}

Public law principles of transparency, public participation, and accountability have been neglected in public and private transfers of water service utilities, ${ }^{166}$ but infusing these principles into the privatization process has the potential to address access to water challenges: they function to reduce instances of corruption, ensure accountability and regulatory enforcement, open doors for funding through accountable private sector participation, and reestablish trust in government. ${ }^{167}$ Such democratic accountability procedures can help facilitate communication between citizens and the government. Protected procedural rights help make democracy possible; they are essential for putting democracy into practice. ${ }^{168}$ While procedural rights grounded in principles of transparency, public participation, and accountability are not a panacea for access to water challenges, these procedural rights and principles give force and clarity to a substantive human right to water. ${ }^{169}$

\section{A. Improving Democratic Accountability Through Public Law Principles}

\section{Transparency}

Transparency is the promise of access to information. ${ }^{170}$ An informed public is able to recognize and bring attention to issues that may arise under a certain course of action before decisions are finalized. ${ }^{171}$ Additionally, when other means for oversight are lacking, an informed public may be able to challenge questionable practices. Transparency

166. Bolivia is just one example, but the events in Indianapolis raise questions as well. Other instances are observed in AKECH, supra note 10 (Tanzania, Kenya, and Uganda).

167. See Bende Toth, Public Participation and Democracy in Practice-Aarhus Convention Principles as Democratic Institution Building in the Developing World, $30 \mathrm{~J}$. LAND RESOURCES \& ENVTL. L. 295, 328-39 (2010).

168. Id.

169. See generally id. (analyzing the Aarhus Convention on Access to Information; although this convention applies to environmental concerns, it does not address drinking water specifically), accord CARE USA \& CARE DENMARK, THE HUMAN RIGHT TO WATERBEYOND ACCESS, SUBMISSION TO THE OFFICE OF THE HIGH COMMISSIONER ON HUMAN RIGHTS (2007).

170. See Barnali Choudhury, Recapturing Public Power: Is Investment Arbitration's Engagement of the Public Interest Contributing to the Democratic Deficit, 41 Vand. J. Transnat'l L. 775, 809-10 (2008).

171. Toth, supra note 167 , at 297. 
helps to minimize opportunities for corruption. ${ }^{172}$ Moreover, transparency paves the way for the second and third democratic principles-public participation and accountability. ${ }^{173}$ Without access to information, the public cannot fulfill its role in the second principle; without information, there is diminished knowledge of a justiciable issue; and without details of adjudicatory outcomes and reasons for those outcomes, legitimacy is lost. ${ }^{174}$ The benefits to be gained from public participation and the essence of access to justice are significantly watered down without transparency. ${ }^{175}$

But for these benefits to be a reality, transparency requires adequate access to information. ${ }^{176}$ Transparency can fall on a spectrum: on one end, information is available but may be disorganized or difficult to find and attain, and on the other end states may take much more proactive roles to collect and disseminate information. The preference, of course, is that information should be easily accessible, clear, and readily available. So called "sunshine laws" such as the Freedom of Information Act in the United States, or the Promotion of Access to Information Act in South Africa give citizens legal power to demand transparency. ${ }^{177}$ Bolivia, on the other hand, does not have a similar statutory protection for access to information beyond the protection of freedom of speech in the Constitution. ${ }^{178}$

If sunshine laws can be applicable to government contracts with private entities, it is possible that citizens could express concerns regarding the effect that some provisions might have on their livelihoods. In Bolivia, secret contract negotiations, bidding processes, expedited legislation, and unpublished contracts, among other issues,

172. E.g. Hale, supra note 8, at $788-89$ (lack of transparency and public participation in Manila's regulatory agencies opened opportunities for corruption in the privatization process); AKECH, supra note 10, at 68 (litigation in the International Centre for Settlement of Investment Disputes revealed that City Water management threatened to "try to force the hand of the [Tanzanian] government" if it would not be willing to renegotiate the concession agreement) (quoting Biwater Gauff (Tanzania) Ltd. v. United Republic of Tanzania, ICSID Case No. ARB/05/22, Award, I 182).

173. See, e.g., Choudhury, supra note 170, at 811 (discussing lack of access to information in arbitrations in the International Centre for the Settlement of Investment Disputes).

174. Id.

175. See Toth, supra note 167, at 299 (discussing how a lack of transparency about "environmentally significant information" frustrates authorities and the public).

176. Id. at 298 .

177. See generally Freedom of Information Act, 5 U.S.C. $\S 552$ (2009); Promotion of Access to Information Act 2 of 2000 (S. Afr.).

178. Freedom House, Freedom of the Press 2010: Bolivia, U.N. HIGH COMM'N FOR REFUGEES (Oct. 1, 2010), http://www.unhcr.org/refworld/country,,FREEHOU,,BOL, 4ca5cc65a,0.html (last visited Aug. 23, 2012). 
are all indications of a severe lack of transparency. ${ }^{179}$ Transparency in each of these stages, as well as in the post-contract regulation stage, is necessary to ensure access to clean water. It bears mentioning that the Inter-American Commission on Human Rights highlighted the lack of communication between different sectors of society in Bolivia and recommended that the government take steps to improve the channels of communication to minimize mass demonstrations and prevent conflict escalations. ${ }^{180}$

The U.N. Report of the Independent Expert on the issue of human rights obligations and access to water outlines several practices that both state and nonstate actors should adopt to increase transparency. ${ }^{181}$ Once a state decides to privatize water services, the state must construct an implementation plan for the transfer of the utility to a prospective private entity. ${ }^{182}$ To protect the human interest in safe and accessible drinking water, the plan must be disclosed to the public and made open to criticism. ${ }^{183}$ Moreover, that information should offer details as to the "instruments that delegate service provision," 184 such as the proposed contract. A corporation's interest in maintaining the confidentiality of the contract jeopardizes the interest in transparency. ${ }^{185}$ Complete confidentiality of such terms can present risks to the realization of the human right to water, and governments and private entities should take steps to minimize that risk. The bidding process is also an important point for transparency. According to the Report of the Independent Expert, companies allegedly underbid for the purposes of winning the contract and then later renegotiating for a higher price. ${ }^{186}$ Renegotiations of the contract are not inherently problematic, but strategic underbidding is contrary to the interest of

179. See generally Sánchez-Moreno \& Higgins, supra note 55 (examining corporate conduct and the Bolivian government's role protecting economic, social, and cultural rights).

180. INTER-AM. COMM'N H.R., ACCESS TO JUSTICE AND SOCIAL INCLUSION: THE ROAD TOWARD STRENGTHENING DEMOCRACY IN BoLIVIA If 16, 45 (2007), available at http://www.cidh.org/countryrep/Bolivia2007eng/Bolivia07cap1.eng.htm.

181. Rep. of the Independent Expert on the Issue of Human Rights Obligations Related to Access to Safe Drinking Water and Sanitation, Human Rights Council, U.N. Doc. A/HRC/15/31 (June 29, 2010) (by Catarina de Albuquerque) [hereinafter "Report of the Independent Expert"].

182. See, e.g., id. at I 63(a) (suggesting that states should implement an action plan with human rights concerns in mind).

183. See id. at 134 .

184. Id.

185. See, e.g., Dickinson, supra note 31 , at 192 (private contractors with the U.S. government can choose not to comply with Freedom of Information Act requests for the sake of protecting trade secrets and other confidential information).

186. Report of the Independent Expert, supra note 181, at $\uparrow 36$. 
transparency and due diligence. ${ }^{187}$ The responsibility for minimizing the possibility of these risks falls on both states and corporations.

\section{Public Participation}

"Public participation is a critical element for democratic governance since it is essential for the realization of a just society." 188 It is through public participation that citizens can ensure that their needs are fully met. It "enhances the viability of policy initiatives," improves chances for successful implementation, and establishes a sense of legitimacy in the outcome. ${ }^{189}$ It should be noted that it is difficult to make participation truly "public," especially for the poor and marginalized groups who are sometimes silent in policy dialogue because they are unfamiliar with the relevant jargon or are outright ignored. ${ }^{190}$ Still, public participation is essential to the fulfillment of democratic governance. ${ }^{191}$

In the context of water management, public participation fosters a dialogue with those that are or will be affected by the decisions of state or private actors. Such decisions will have consequences for the environment and communities. Participation in the decision-making, planning, and regulation processes will facilitate general understanding of all the interests at stake and promote a plan for universal access to water in a given community. ${ }^{192}$

Especially in developing countries like Bolivia, governments experienced pressure from foreign actors to move toward privatization. ${ }^{193}$ Such pressures encouraged governments to move forward without incorporating insights from the affected communities. ${ }^{194}$ Public participation is at the very heart of democracy and such pressure without consultation undermines it. ${ }^{195}$ Additionally, the requirement of consultation and public participation can serve to reduce opportunities for discrimination. The U.N. Independent Expert,

187. E.g., AKECH, supra note 10, at 67-68 (in the Tanzania experience, the private company underbid and misrepresented its ability to perform the terms of the contract).

188. Id. at 32 .

189. Id. at 33 .

190. Id.

191. See id. at 32.

192. Report of the Independent Expert, supra note 181, at $\$ 34$.

193. See Toth, supra 167, at 297 (describing various types of pressures a government may feel).

194. See Report of the Independent Expert, supra note 181, at I 35 (advising that decisions of when to delegate to nonstate actors "should always be taken in the light of local circumstances.").

195. AKECH, supra note 10 , at $32-33$. 
in a separate report, observed that in the United States the groups that suffered from limited access to water "were disproportionately Black, Latino, American Indian, [and] homeless." 196 The plaintiffs in Mazibuko v. City of Johannesburg and the residents in Cochabamba demonstrate the same inequality in developing counties. ${ }^{197}$ "The decision for, or against, delegating service provision to non-State actors should always be taken in light of the local circumstances." ${ }^{198}$ Participation should not be limited only to residents either. NGOs and corporations have an important role to play as a voice for public, environmental, and other concerns that may otherwise be underrepresented. ${ }^{199}$

Because private water service providers are often saddled with the responsibility of managing water delivery services in addition to making significant investments for water infrastructure expansion and improvement projects, such actors are susceptible to serving neighborhoods or regions that will yield the greatest financial returns. ${ }^{200}$ Public participation and consultations will minimize these effects, but the onus must fall on the state to mandate private water providers to extend their services to under- and un-served communities. ${ }^{201}$ The state bears the ultimate responsibility not to discriminate, to dedicate particular attention to marginalized groups, and to ensure the realization of a right to water. ${ }^{202}$ If a private entity is not able to provide services to certain areas, the government should consider whether subsidies and other tools might be employed to ensure access to water is achieved. But that does not mean private entities are relieved of all responsibility. Corporations contracting with the state are in an ideal position to proactively raise concerns of discrimination or limited coverage with the state; both governments and private entities must work together to carefully ensure that their contracts provide coverage for all. ${ }^{203}$ Through open participation, consultation, and careful analysis

196. Special Rapporteur on the Human Rights to Safe Drinking Water and Sanitation, Rep. of the Special Rapporteur on the Human Right to Safe Drinking Water and Sanitation, 179 , Human Rights Council, U.N. Doc. A/HRC/18/33/Add.4 (August, 2011) (by Catarina de Albuquerque).

197. See Mazibuko 2010 (4) SA 1 (CC) I 10 (Phiri, where the plaintiffs lived, was a predominantly poor, black neighborhood due to the effects of former apartheid urban planning policies); See also Sánchez-Moreno \& Higgins, supra note 55, at 1777-78 (the Bolivian government did not consider issues of equity in its contract with AdT, and poorer neighborhoods' rates increased disproportionately higher than others).

198. Report of the Independent Expert, supra note 181, If 35.

199. Toth, supra note 167 , at 320 .

200. Report of the Independent Expert, supra note 181, I 39.

201. Id. I 40 .

202. See id. ๆ 17.

203. Id. ๆ 42 . 
of coverage strategies and contract terms, both corporations and governments can improve access to drinking water.

\section{Accountability with Transparent and Equitable Outcomes}

Accountability is also critical because it deepens the relationship between those in a position to wield power and those affected by such power. ${ }^{204}$ It gives citizens the right to hold such actors "to a set of standards, to judge whether they have fulfilled their responsibilities in light of these standards, and to impose sanctions if they determine that these responsibilities have not been met." ${ }^{205}$ In this way, accountability fosters a more just exercise of power, creating incentives and enforcement mechanisms that comport with individual rights and liberties. $^{206}$

An additional criticism of the Bolivia water disaster was that the contract permitted AdT to file for arbitration at the International Center for the Settlement of Investment Disputes (ICSID), where it sought $\$ 25$ million for its lost investment. ${ }^{207}$ AdT successfully argued that a bilateral investment treaty between the Netherlands and Bolivia provided the necessary consent for both parties to be subject to arbitration at ICSID. ${ }^{208}$ But because ICSID functions at the consent of and under the arbitration terms agreed upon by the parties, AdT was able to request that proceedings be kept private-no members of the press or the public could attend and all evidence presented to the panel was confidential -and the tribunal honored that request by denying a petition from Cochabamba residents requesting that ICSID intervene on their behalf. ${ }^{209}$ Eventually, the case was dropped and the parties agreed to a settlement. ${ }^{210}$ In protecting the human right to universal access to clean water, states must be responsible for ensuring access to courts with transparent and equitable outcomes, while private entities must be careful not to adopt practices or seek contract terms that "obstruct

204. AKECH, supra note 10 , at 33 .

205. Id. (quoting Ruth W. Grant \& Robert O. Keohane, Accountability and Abuses of Power in World Politics, 99 AM. POL. SCI. REV. 29, 29 (2005)).

206. Id.

207. Sánchez-Moreno \& Higgins, supra note 55, at 1771-72.

208. Aguas del Tunari, S.A. v. Republic of Bolivia, Case No. ARB/02/3, Decision on Respondent's Objections to Jurisdiction, 19 3, 7 (Oct. 21, 2005), 20 ICSID Rev. 450 (2005), available at http://icsid.worldbank.org/CSID/FrontServlet?requestType=CasesRH\&actionVal= showDoc\&docId=DC629_En\&caseId=C210.

209. Sánchez-Moreno \& Higgins, supra note 55, at 1773.

210. Aguas del Tunari S.A. v. Bolivia, ICSID Case No. ARB/03/2, Introductory Note, Sept. 28, 2006, 20 ICSID Rev. 445, 449 (2005). 
access to State-based accountability mechanisms, including court proceedings."211

Regulations are toothless without access to judicial accountability and restitution. ${ }^{212}$ To ensure accountability, the roles and responsibilities between public and private actors in water services must be clearly defined and made apparent to the public. ${ }^{213}$ In this way, consumers or other injured parties will know whom to hold accountable for reprehensible actions and violations. ${ }^{214}$ Access to justice also means that lawsuits should not be so expensive that individuals cannot afford to bring a suit. ${ }^{215}$ Additionally, states should ensure that complaints are adequately and thoroughly addressed and allow possibilities for appeals. ${ }^{216}$ Finally, remedies must be delivered in a timely manner so that cases do not become bogged down in the courts so long that they become futile to continue. ${ }^{217}$

\section{B. Application of Administrative Law and South Africa's Promotion of Administrative Justice Act}

If it is accepted that democratic accountability through public law principles is essential to protecting human rights in privatization practices, then it must be asked how states can implement the corresponding principles of transparency, participation, and accountability. One option is through administrative law reform. The value of administrative law is that it regulates those who exercise public power. ${ }^{218}$ Administrative law secures the protection of rights by requiring officials to "follow fair and impartial decision procedures, act within the bounds of statutory authority delegated by the legislature, and respect private rights." ${ }^{219}$ In essence, administrative law elaborates on duties that constitutional and statutory. provisions create. Administrative law also plays an important watchdog role. It is a body

211. Report of the Independent Expert, supra note 181, 1 \59, 62(f).

212. See id. $1952-60$.

213. Id. ๆ 57.

214. Id.

215. See Toth, supra note 167, at 311 (discussing that NGOs and citizens' groups can help alleviate issues of costs for individuals in bringing a lawsuit).

216. See id. at 312 (explaining that under Article 9(2) of the Aarhaus Convention signatories are to "ensure access to a review procedure," which may include appeals).

217. See id. (stating there is a need for adequate remedies that are "fair, equitable, timely and not prohibitively expensive"').

218. See AKECH, supra note 10, at 138-39.

219. Id. at 138 (quoting Richard B. Stewart, Administrative Law in the Twenty-First Century, 78 N.Y.U. L. REV. 437 (2003)). 
of law that can be used to ensure agencies fulfill statutory obligations. ${ }^{220}$ Finally, administrative law typically combines all three elements of public law to facilitate cohesion between the exercise of public power and the public interest. ${ }^{221}$ However, in many countries administrative laws are only enforceable against state actors. ${ }^{222}$ In democratic countries that continue to engage the private sector in the operation and management of water systems, there is a need for reforms that will hold private actors exercising public power democratically accountable. ${ }^{223}$

In searching for models of administrative law available for deepening democratic accountability, South Africa again offers a pragmatic example of an administrative law statute that incorporates public law principles to protect human rights, including the right to water, against both state and private entities exercising public power. ${ }^{224}$ South Africa passed the Promotion of Administrative Justice Act of 2000 (PAJA) to give effect to the right to "administrative action that is lawful, reasonable and procedurally fair," ${ }^{225}$ and to promote the obligation to provide reasons for administrative actions that affect rights under Section 33 of the Constitution. ${ }^{226}$ The principle tenants of the PAJA require administrators to (1) follow certain procedures when making decisions; (2) give adequate reasons for decisions upon request; (3) inform individuals of their rights to review and appeal administrative decisions; and (4) allow individuals to challenge administrative actions. ${ }^{227}$ Thus, the PAJA elaborates on a bare right to administrative protections in the Constitution. It explains how officials must proceed in order to give effect to constitutional rights and directives. ${ }^{228}$

220. Id.

221. Alfred C. Aman, Jr., Globalization, Democracy, and a Need for a New Administrative Law, 10 IND. J. GLOBAL LEGAL STUD. 125, 147 (2003).

222. E.g., Administrative Procedure Act, 5 U.S.C. $\$$ 551(1) (2011) (defining that the general administrative law statute in the United States only applies to federal government agencies under the Administrative Procedure Act).

223. See Aman, supra note 221 , at 152.

224. See generally Caron Beaton-Wells, Administrative Law in South Africa: No Longer a "Dismal Science" (Melbourne L. Sch. Legal Studies Research Paper No. 397, 2003), available at http://papers.ssrn.com/sol3/papers.cfm?abstract_id=1407372 (comparing South Africa's and Australia's administrative laws and the strengths of the South Africa model).

225. S. AFR. CoNST., 1996, § 33.

226. Beaton-Wells, supra note 224 , at $86-89$.

227. IAN CURRIE ET AL., DEPT. OF JUST. \& CONST. DEV., ADMINISTRATOR'S GUIDE: ThE Promotion of Administrative Justice ACT 12 (Greg Moran ed., 2d ed. 2006) (S. Afr.), available at http://www.fs.gov.za/information/documents/legal\%20services/admin\% 20guide\%20prom\%20admin\%202nd\%20edition.pdf.

228. The Promotion of Administrative Justice Act, Introduction, DEPT. OF JUST. \& CONST. DEv., http://www.justice.gov.za/paja/about/intro.htm (last visited Nov. 14, 2012) (S. Afr.); Promotion of Administrative Justice Act 3 of 2000 pmbl. (S. Afr.). 


\section{Applicability to Private Actors}

An administrative action under the PAJA is "a decision . . . that is of an administrative nature made in terms of an empowering provision ... that is not specifically excluded by the [PAJA] . . . by an organ of the state . . . that adversely affects rights."229 A decision that is "of an administrative nature" is one that is carried out as part of official duties according to laws that allow actors to make decisions. ${ }^{230}$ "[O]rgan[s] of [the] state" are defined in South Africa's Constitution as "functionaries or institutions . . exercising a power or performing a function in terms of any legislation." 231 This has significant implications for water privatization because the PAJA can apply to private actors when they are performing public roles, such as managing water delivery systems. ${ }^{232}$ A private entity's decision to act or not to act may be required to adhere to the same procedure and explanation requirements as public entities. Thus, the PAJA strives to prevent deregulation from accompanying privatization, allowing the bridge between citizens and private providers of public goods to remain intact. ${ }^{233}$

\section{Procedural Fairness}

Procedural fairness under the PAJA means that the process must be free of bias and partiality, and it must give adversely affected individuals, or the public generally, a reasonable opportunity to be heard. ${ }^{234}$ To accomplish this objective, the PAJA mandates that those who will be adversely affected by an administrative action must be given notice of the pending administrative action and an opportunity to make arguments. ${ }^{235}$ Individuals must also have access to explanations of what the proposed action is and why it is being proposed. ${ }^{236}$ Additionally, when a decision is reached, administrators must give a clear reason for the decision as well as notice of the right for review or to

229. CURRIE, supra note 227 , at 14 .

230. See id. at 16; see also Beaton-Wells, supra note 224 , at 94 (the test for "administrative in nature" depends on the action rather than the who the decision maker is).

231. S. AFr. CoNST., 1996, § 239.

232. See CURRIE, supra note 227 , at 17 (stating that a private company that contracts with a municipality for the supply of water would be covered by the PAJA).

233. See Aman, supra note 20, at 549-50.

234. CURRIE, supra note 227 , at $23-24,30$.

235. See id. at 24-25 (explaining how notice involves more than informing a person).

236. See The Promotion of Administrative Justice Act, Reasons, DEP'T OF JUST. \& CONST. DEV., http://www.justice.gov.za/paja/about/reasons.htm (last visited Nov. 14, 2012) (S. Afr.). 
appeal. ${ }^{237}$ Thus, the PAJA requires transparency of information and outcomes in the course of public participation in administrative decisions.

The degree of public participation, however, varies depending on the circumstances-a person may be entitled to a hearing or merely permitted to submit a written statement. ${ }^{238}$ Administrators have discretion to allow legal representation in the proceedings, to allow the right to confront adverse witnesses, and to allow in-person appearances during the proceeding. ${ }^{239}$ But the PAJA also provides that municipalities must find ways to encourage public participation in government decisions. ${ }^{240}$ Additionally, the government is required to promote transparency by furnishing information and ensuring it is accessible and accurate. ${ }^{241}$

\section{Reasonable Explanations}

Finally, administrators must give adequate, written explanations for their administrative action upon request, though they are free to give explanations for all decisions. ${ }^{242}$ Upon judicial review, the explanations are judged by their reasonableness considering the information available at the time the decision was made. ${ }^{243}$ The fact that explanations are not required with a decision threatens the legitimacy of outcomes because it presents the opportunity for post hoc rationalizations. ${ }^{244}$ Additionally, a requirement that explanations must be reasonable is likely to lead to highly deferential decisions from courts upon judicial review. ${ }^{245}$ Although not decided under the PAJA, Mazibuko $v$. City of Johannesburg is indicative of the deferential outcomes of a "reasonable explanation" requirement. In the context of administrative decisions affecting fundamental human rights, it is likely preferable that such explanations of administrative decisions should offer more. Nevertheless, this arrangement is better than no required explanation at all. Additionally, explanations must be "satisfactory," meaning that

237. CURRIE, supra note 227 , at 25.

238. Id.

239. Id. at 26.

240. MCDONALD \& RUITERS, supra note 9, at 64 .

241. Id.

242. CURRIE, supra note 227 , at 29.

243. Id. at 36 .

244. See, e.g., Alfred C. Aman, JR. \& William T. Mayton, Administrative Law, 51012 (Westlaw Sch. Advisory Bd. ed., 2d. ed. 2001) (discussing the requirement under the Administrative Procedure Act that agencies give reasons that are contemporaneous with the agency's policy decisions).

245. See id. at 512 (using the term "rational agency explanation"). 
they must offer details that convey the reasons for the outcome and cannot be mere recitations of statutory authority. ${ }^{246}$

Although the PAJA is not perfect, the existence of comprehensive administrative laws does much to ensure public participation, transparency, and accountability in government decisions. Equally important is the applicability of the PAJA to private entities. The PAJA demonstrates that constitutional and human rights may be better protected through the process of privatization when government and private actors are legally bound to follow procedures that foster democratic accountability.

\section{CONCLUSION}

Water is something everyone must have. There are individual and societal considerations that must be factored into how it is managed, and that responsibility falls first to states. The recognition of water as a human right reinforces that responsibility and is a positive step toward universal access to clean, drinkable water. But a legal framework that fosters democratic accountability with public law principles must complement that right.

South Africa is a unique and informative case study for considering ways to privatize water delivery systems in ways that respect and secure a human right to water. Recognizing the human right gives citizens a position from which to demand state accountability for privatization decisions. Meanwhile the reasonableness approach of South Africa's Constitutional Court affords the state flexibility in determining how to take progressive steps toward fulfilling that right with limited resources. Finally, the PAJA reinforces the right to water with procedural requirements. Developing administrative laws that require transparency, public participation, and accountability that apply to public and private actors will legitimize decisions to privatize, will better adhere to the concerns of the poor and marginalized groups, and will give governments flexibility to choose policies that comply with human rights. South Africa's legal framework offers mechanisms to plug the democracy drain and may be a useful model for other developing counties grappling with privatization in human rights interests. By improving democratic accountability in water services, we will be closer to reaching universal access to clean water.

246. CURRIE, supra note 227 , at 30 . 
